\title{
NEED ANALYSIS OF ESP FOR NON-ENGLISH STUDY PROGRAM
}

\author{
Rini Ekayati, Imelda Darmayanti Manurung, Elvita Yenni \\ University of Muhammadiyah Sumatera Utara (UMSU), Medan, Indonesia \\ E-mail: riniekayati@umsu.ac.id
}

Received: 15 November 2020

Accepted: 15 December 2020

\begin{abstract}
In non-English study programs, English learning material is arranged based on the specificities of the English learners themselves, commonly known as English for Specific Purpose (ESP). By using a qualitative approach and descriptive method, this study aims to map the students' English language skills, determine the objectives of learning English, and the concept of ESP material needed by students in the non-English Study Program at UMSU. Sources of data in this study were 80 (eighty) respondents (students) from non-English study programs who had already completed their general English course. Data analysis was performed by using qualitative descriptive methods in terms of numbers and percentages. The results show that the students' needs vary from one student to another depending on their respective fields of knowledge. The students' average ability starts from the low until intermediate level, and speaking and listening skills cover those needed by the learners of the respective study program. Their learning objectives are divided into two criteria, short-term goals related to current needs such as academic/educational needs and long-term goals related to their world of work after completing education. The concept of ESP English learning needed depends on the varying needs of each existing non-English study program. Thus, the ESP concept that is designed must be adapted to these needs.
\end{abstract}

Keywords: needs analysis, English learning, ESP, non-English learner's needs, ESP Design.

\section{Introduction}

In the Indonesian context, English has begun to be taught from elementary school to Higher Education, which at each level there are levels of mastery of English skills that are not the same. For Higher Education level, English learners should have started is devoted to the development of the ability to communicate by the scientific fields they choose. This is because almost all study programs in Higher Education provide English courses for 1 or 2 semesters in each of their study programs, including non-English study programs. This further indicates the importance of mastering English Britain as a foreign language used in the current era of globalization, which once served as one of the students' academic success as well as an introduction to their careers in the world of work later (Megawati: 2016).

Furthermore, at the level of universities, students as English learners are assumed to already have basic skills sufficient knowledge of English grammar that supports the ability to communicate in English automatically. However, this is contrary to the facts. There are still weaknesses of English learners regarding the topic of basic grammar in English, namely regarding the subject-verb agreement with a fairly high average percentage of $95 \%$ errors 
(Ekayati: 2014). This can affect their ability to communicate in English, where grammar understanding is the basis for sentence formation in the English system.

At Universitas Muhammadiyah Sumatera Utara (UMSU), subjects of English obtained a student in the 1st half with a load of as much as 2 credits to all existing courses, including English Language Study Program. Especially at the Faculty of Social and Political Sciences, English courses programmed in two semesters i.e. semesters 1 and 2 with each load of credits is 2 credits. In general, the purpose of learning English is to provide an understanding of the linguistic aspects of English to be used in communication. Especially for non-English Studies, English Language course aims for non-English learners to know and can use English by the scientific field in the context of listening, speaking, reading, and writing, both formal and informal. However, this has not been achieved completely.

In the learning process, English courses, especially those taught in the non-English Study Program in UMSU are still oriented to the application of the concept of General English (General English= GE), where the material presented revolves around understanding English in general concepts, not focused on one scientific field. This of course does not optimize the objectives of learning English itself. For students in the non-English Study Program, the concept of learning English is needed which is intended for certain learners with specific goals as well. This concept is offered in this study, namely the concept of learning English with a specific purpose, or what is called the English for Specific Purpose (ESP). ESP can provide multiple benefits for students (pre-experienced students), namely: 1) academic interests (when studying), and non-academics (for everyday purposes), and 2) students' readiness to enter the world of work in accordance with their field, where their English language skills can be the capital to compete and be competent in the world of work which requires being able to speak English. (Kusumaningputri, 2016). Besides, the analysis of the needs of ESP learners must be carried out continuously because the purpose of ESP learning itself is to address the needs of the learners that are not the same or keep changing. (Adnan, (2012). Therefore, English courses in the existing non-English study programs need to be transformed into ESP English courses as a policy in developing the existing curriculum, so that non-English Language Study Program students can benefit the double. In addition, later the results of this study can be used as an evaluation material for the ongoing process.

\section{Literature Review}

\subsection{Needs Analysis Assessment}

In the world of education, the learning process is one of the most important parts. This is because, in the learning process, the goals, achievements, or results of the educational process are determined. When this process goes well, the results will be good, as well as other things. However, the learning process does not always go well, sometimes obstacles arise in the process. These constraints arise due to various factors, one of which is the lack of learning planning that will be carried out during the learning process. On the other hand, to prepare a good lesson plan to be able to maximize the results as expected is not an easy matter. And before compiling the lesson plan, it is necessary to first analyze the needs of the learner (student). This is intended so that later the learning material/content received by learners is something that is needed by them. This is why it is necessary to conduct a needs analysis to correctly determine the learning needs that will be carried out.

Needs analysis is a way or method to determine the difference between the desired condition / should / expect (should be / ought to be) with existing conditions (what is).The desired conditions are ideal conditions that are expected to occur, whereas the existing 
condition is a condition that occurs in practice. Furthermore, the needs analysis is not a result, but a certain activity in a bid to make certain decisions. The decision to be taken is the need to resolve the gap between expectations and reality. Thus, the needs analysis is the activity of collecting information about the gap between expectations and the reality experienced by learners in a learning process.

Hutchinson and Waters (1987) classify the needs, needs, into: 1) target needs, they are; the needs needed by learners to be able to communicate when in a situation target, and 2) learning needs that is related to what learners need to learn. Furthermore, based on these needs, the most important needs are the needs of the learners (target needs), where target needs are divided into three things, namely necessities, wants, and lacks. Need is to see what learners need to know to function properly and communicate efficiently on target. Meanwhile, desire is what the learner wants in learning certain things. Whereas shortcomings are the distance or gap between what learners know and which parts they don't know or don't know so that learning must focus more on this. (Febriyanti, 2017)

In practice, the needs analysis involves the implementation of Target Situation Analysis (the needs of learners with language learned in the future), the Present Situation Analysis (do learners with language learned at this point), and Context Analysis (how the environment in which learning will take place). (Westerfield (2010) in Hossain (2013)). Overall the information obtained from the analysis of needs is what will be used in determining the content of the material or enhance and ESP learning methods.

Currently, the needs analysis has been growing, not only includes analysis of requirements regarding the use of language and skills in the target situation but also concerning the analysis of learner factors and context of teaching itself. Research on this subject has been running for the last few decades and is carried out by many researchers. Kothalawala et al. (2015) in Febriyanti (2017) summarizes some model or approach taken by previous researchers from simple models to the most complex, as illustrated in Table 1 below. Table 1: Models and Approaches of Needs Analysis

\begin{tabular}{l} 
Need Analysis Type \\
\hline 1. Register Analysis \\
2. Communicative Needs Processor \\
3. Deficiency Analysis \\
4. Learner-Centered Needs Analysis \\
5. Target Situation Analysis \\
6. Critically Aware Needs Analysis
\end{tabular}

7. Right Analysis Researcher

Peter Strevens, Jack Ewer, and John

Swales -1960 s and 1970s

Munby (1978)

West (1997); Brindley (1989)

Nunan (1988)

Hutchinson and Waters (1987)

Holliday and Cooke (1982); Selinker (1979) and Swales (1990); Tudor (1997); Douglas (2000); Murray and McPherson (2004); JassoAguilar (1995,1998); Carter- Thomas, (2012); Huhta, Vogt \&Ulkki (2013

Benson (1989); Goer (1992); Smoke (1994); Leki (1995); Prior (1995); Spack (1997); Benesch (1999, 2001); Dudley Evans and St. Johns (2001). 
8. Stakeholder Needs Analysis

Jass-Aguilar (1999); Long (2005); Cheng

(2011); Belcher \&Lukkarila (2011);

Paltridge\&Starfield (2013); Huhta, Vogt \&Ulkki

(2013)

Some of these models are influential in the development of ESP.

\subsection{Learning English in Higher Education}

As one of the educational institutions in Indonesia, University (PT) plays a very important role in creating human resources (HR). The demands of today's developments place the position of PT in the top place in terms of educating the next generation of the nation who can compete in today's open global world. A country's openness to the outside world will have an impact on the country's readiness to accept the openness that comes. More foreigners will enter and interact with residents. Here, the role of foreign languages is indispensable.This is what is now needed and expected from graduates of the college, where the Human Resource college graduates are equipped with skills in mastering a foreign language, such as English.

But in reality, it is precisely the weakness of human resources in Indonesia college graduates lies precisely in their English language ability. The weakness of this English language course should be resolved, one way to improve the process of learning English there. In the college curriculum, courses of English at the beginning of independence up until the early 1970s are still deployed as a complementary course then turn into general courses until the early 1980s, the general basic subjects, and this time the college has the freedom to determine basic subjects (Afriazi, 2016).

With the challenges currently faced by universities in producing graduates with a good mastery of English, of course, faculty and student task is not easy. With 2 credits of English courses which only last 1-2 semesters, it is not an easy job to create Human Resources who have sufficient English skills. Lecturers and students must work together in the learning process. Lecturers should be able to design lesson plans that can meet the needs of students to English, and applying ESP in teaching can be overcome, namely by using a variety of learning resources and media and innovative. (Hamidah \& Yanuarmawan, 2019). On the other hand, students should also be able to optimize its efforts in understanding the English language itself. Thus, the obstacles that may exist can be resolved together.

ESP or English for Specific Purpose was introduced by Hutchinson and Waters (1987). ESP is an approach to learning English which is more oriented to the learning process. ESP approach is designed with the needs of English learners that includes aspects of English language learners what the need, in the context of what the learners to learn English, and what goals you want to achieve English study in particular. So that ESP is process-oriented which determines the skills and components of English related to the needs of the learners.

Furthermore, Hutchinson and Waters (1987) explained that ESP is an approach to learning English in which the learning topics and methods used in the learning are designed based on the needs of why learners want to learn English. In other words, learners have a special reason or purpose in learning English. This is what underlies the difference between learning English in general (General English) and learning in particular (English for Specific Purposes).

To demonstrate the position of ESP in teaching English, language teachers consider ESP to be a branch of ELT (English Language Teaching). Furthermore, ESP has the following characteristics: 


\section{a. Absolute Characteristics:}

Method in absolute terms, ESP is designed to meet the special needs of learning English by using methodologies and learning activities that are in accordance with the scientific field of the English learners themselves. ESP learning focuses on activities in the aspects of language (grammar, lexis, and registers), language skills, and types of discourse or text that are in accordance with the learner's area of expertise.

\section{b. Variable Characteristics:}

The ESP variable can be related or designed for certain disciplines so that it can be used as a special form of teaching with a different methodology from learning English in general. The ESP program is intended for adult learners, either formally as an institutional or professional field. However, it can also be applied to intermediate level learners, especially certain vocational programs. ESP learners should already have a basic knowledge of English, even at a beginner level

In the context of higher education, students take English course not only based on their desire to learn English, but also because they have to take this subject as one of the compulsory courses, even if they like it or not. Therein lays the challenge of English teachers, especially in non-English study programs to make this course meaningful and useful for these students.

Based on this description, the term 'specific' in English for Specific Purpose refers to the specificity of learning objectives, not to jargon or registers in English. The concept of ESP can be understood from its position in the realm of English Language Teaching (ELT) studies.

Not a few students in non-English study programs feel that their English language skills are still very low. These weaknesses include reading, writing, speaking, and listening / listening skills. Some thought they were weak in speaking and writing skills, so they hoped that the English learning they would acquire would focus on these two skills. (Asnadi, 1990 in Febriyanti, 2017). Based on this description, the term 'specific' in English for Specific Purpose refers to the specificity of learning objectives, not to jargon or registers in English. The concept of ESP can be understood from its position in the realm of English Language Teaching (ELT) studies.

\section{Research Method}

The method used in this research is a descriptive and qualitative approach that is natural to the presentation of data in the form of numbers and percentages. The data analysis was conducted through data collecting, data reduction, data display, and conclusion drawing (Sugiyono, 2010). The source of qualitative data was 80 respondents (students) from nonEnglish study programs in the UMSU environment who were or had completed general Basic English courses. The instrument used is a close-ended questionnaire is a form of a questionnaire that has an answer that can be directly selected by the respondents.

\section{Results and Discussion}

In this study, data processing was based on the results of filling out a questionnaire containing 28 questions. Each instrument used in this study is intended to answer research problems related to how the English language skills of non-English Study Program students in general, what are the students' goals in learning English in the non-English Study Program, and 
what are the concepts ESP material needed by students in the non-English Study Program at UMSU. In distributing the questionnaire used the online Google form facility.

First to the third question in the questionnaire is about how English language respondents categorize their current English language skills (present situation analysis) containing estimates of strengths or weaknesses in language, skills, and learning experiences as the first step in needs analysis. The distribution of respondents' answers can be seen in the following table:

Table 2: General Ability of Students in English

\begin{tabular}{ccc}
\hline Rankings & Amount & Percentage (\%) \\
\hline Beginner & 35 & 43.75 \\
\hline Intermediate & 44 & 55 \\
\hline Advanced & 1 & 1.25
\end{tabular}

In the table above, it is shown that the majority of English language skills of non-English study program students were at the intermediate level (55\%), while at the beginner level it is $43.75 \%$ and the advanced level is $1.25 \%$. This data only shows the current situation in English language learning in non-English study programs.

Table 3: Students' English Skills for Each Skill

(Reading, Speaking, Listening, and Writing)

\begin{tabular}{lccccccccccc}
\hline \multirow{2}{*}{ Skill } & \multicolumn{2}{c}{ Very good } & \multicolumn{2}{c}{ Well } & \multicolumn{3}{c}{ Pretty good } & \multicolumn{2}{c}{ Weak } & \multicolumn{2}{c}{ Very weak } \\
\cline { 2 - 13 } & Sum & $\%$ & Sum & $\%$ & Sum & $\%$ & Sum & $\%$ & Sum & $\%$ \\
\hline Reading & 11 & 13.75 & 34 & 42.5 & 30 & 37.5 & 4 & 5 & 1 & 7.5 \\
\hline Speaking & 4 & 5 & 26 & 32.5 & 34 & 42.5 & 15 & 18.75 & 1 & 7.5 \\
\hline Listening & 3 & 3.75 & 30 & 37.5 & 37 & 46.25 & - & - & 10 & 12.5 \\
\hline Writing & 6 & 7.5 & 35 & 43.75 & 32 & 40 & 6 & 7.5 & - & - \\
\hline
\end{tabular}

Table 3 above shows the ability of non-English study students for each existing skill, namely reading, speaking, listening, and writing. The data shows that their varying abilities for each existing skill. Most of them have good skills in writing skills, namely $43.75 \%$, even though this writing skill is included in the productivity skill and is quite difficult because it requires mastery of good English vocabulary and grammar. For another productivity skill, namely speaking, students only have the ability at a fairly good level (42.5\%), weak (18.75\%) and very weak (7.5\%). When compared between the two, it can be seen that the learning that has been obtained by non-English Language Study Program students focuses more on writing skills. So it can be said that the focus of learning English is more on scientific knowledge of English, such as English grammar (General English).

As for reading skill, the majority of students' abilities were at a good level of $42.5 \%$, then at a fairly good level of $37.5 \%$, very good at $13.75 \%$, weak by $5 \%$, and very weak at $7.5 \%$, and for listening skills, the majority of students were at a fairly good level of $46.25 \%$, then good at $37.5 \%$, very weak at $12.5 \%$, and very good at $3.75 \%$.

For the next question, it relates to student opinion about the importance of taking English courses for non-English study program students. Apart from the fact that this English course is a compulsory subject that must be followed by non-English study program students, the majority of students think that this subject is very important for them with a percentage value of $71.25 \%$ and $26.25 \%$ important, so that no one considers this subject. English is not important. However, there were 2 respondents $(2.5 \%)$ who said that this course was quite important/ordinary. In full, the data distribution can be seen in table 5.3 below. 
Table 4: How important it is to take English courses

for non-English language education students

\begin{tabular}{lcc}
\hline \multicolumn{1}{c}{ Category } & Sum & Percentage (\%) \\
\hline Very important & 57 & 71.25 \\
\hline Urgent & 21 & 26.25 \\
\hline Quite Important / Average & 2 & 2.5 \\
\hline Not important & - & - \\
\hline
\end{tabular}

The next question is related to the purpose of students taking English courses, apart from the reason that this course is a compulsory subject. The answer to this question also varies with the highest percentage being to communicate fluently both orally and in writing (63.75\%), followed by the goal of studying / education (scholarship/independent) at $13.75 \%$. However, none of the students chose the goal of taking English courses for research and reading English literature. Furthermore, 3 respondents chose other goals in taking the English language course at $3.75 \%$. The details are shown in the table below.

Table 5: Purpose of Taking English Coursesfor Non-English Language Study Programs

\begin{tabular}{|c|c|c|}
\hline Category & Sum & Percentage \\
\hline For study / education (scholarship / independent) & 11 & 13.75 \\
\hline For research & - & - \\
\hline For work & 4 & 5 \\
\hline To go abroad & 1 & 1.25 \\
\hline To communicate fluently both orally and in writing & 51 & 63.75 \\
\hline For personal development & 8 & 10 \\
\hline To read English literature & - & - \\
\hline To learn TOEFL & 2 & 2.5 \\
\hline Other & 3 & 3.75 \\
\hline
\end{tabular}

Based on the table above, it can also be seen thatstudents of non-English study program have different goals with their English skills. The diversity of their responses can be categorized into two types, namely present-oriented learning needs related to academic needs and futureoriented needs related to the world of work. (Robinson, 1991). This of course has a close relationship with the selection of course material taught by the lecturer. As stated by Robinson (1991), if the material taught in this course is in accordance with the needs of the learners, then this will increase learning motivation so that the desired goals will be achieved properly.

For the next question, questions 5-8 are related to what English students need for each existing skill, for example, what they need to read in English, what they need to be listened to, written and spoken in English. The following table shows students' needs in relation to what they need to read in English. Table 6 shows that students not only need to read and understand English books (27.5\%), or lecture materials and journal articles (10\%) but also need to read literature related to their field of study (32.5\%). However, 15 students thought that they didn't only need to read books, journal articles, and lecture materials. They need to read something else (18.75). This data shows that students still need a variety of other reading variations.

Table 6: Required to Read (Reading) in English

\begin{tabular}{lccc}
\hline & Category & Sum & Percentage \\
\hline English books & 22 & 27.5 \\
\hline Journal articles & 8 & 10 \\
\hline
\end{tabular}




\begin{tabular}{lcc}
\hline Magazines and Newspapers & 0 & 0 \\
\hline Lecture material & 8 & 10 \\
\hline Laboratory or other instructions & 1 & 1.25 \\
\hline Read literature related to the field of science & 26 & 32.5 \\
\hline Others & 15 & 18.75 \\
\hline
\end{tabular}

Table 7: Requirements for Listening in English

\begin{tabular}{lcc}
\hline \multicolumn{1}{c}{ Category } & Sum & Percentage \\
\hline Understand instructions/commands & 22 & 27.5 \\
\hline Understand videos / movies / songs & 18 & 22.5 \\
\hline Understand speeches/lectures & 6 & 7.5 \\
\hline Understand seminars/conferences or scientific presentations & 16 & 20 \\
\hline Understand lectures & 7 & 8.75 \\
\hline Others & 11 & 13.75 \\
\hline
\end{tabular}

As for the need for listening, from table 7 above it can be stated that students need to hone listening skills in order to understand instructions/commands (27.5), understand videos/films/songs (22.75\%), understand seminars/conferences or scientific presentations. (20\%), understand the lecture in class (8.75\%), and understand speech (7.5\%). In this listening aspect, data also showed that 11 students chose other answers (13.75\%) for their listening needs.

For writing needs, students' need to learn English is not to be able to write research reports $(0 \%)$, but for other purposes. The main thing is to communicate in writing with other people about the field of knowledge $(21.25 \%)$ and to write something about the field of knowledge (20\%), to translate from and / or to English (17.5\%).

Table 8: Requirements for Writing in English

\begin{tabular}{|c|c|c|}
\hline Category & Sum & Percentage \\
\hline Essay writing assignment & 7 & 8.75 \\
\hline Writing research reports & 0 & 0 \\
\hline Translating from and / or to English & 14 & 17.5 \\
\hline Write an email & 1 & 1.25 \\
\hline Write a summary & 1 & 1.25 \\
\hline Make notes of English lectures & 8 & 10 \\
\hline Write a business letter/job application & 8 & 10 \\
\hline Write something about the field of science & 16 & 20 \\
\hline $\begin{array}{l}\text { Communicate through writing with others about the field of } \\
\text { science }\end{array}$ & 17 & 21.25 \\
\hline Others & 8 & 10 \\
\hline
\end{tabular}

In Table 9 students at the speaking skills (speaking). Based on the table, what students need related to speaking skills is to be able to communicate with other people about the field of science (28.75\%) or with friends/people from abroad (25\%), and also speak at seminars or international conferences (21.25\%). From these data, it can be concluded that students need speaking material related to communication techniques both in formal and informal forums and to foster self-confidence in public speaking. 
Language Literacy: Journal of Linguistics, Literature and Language Teaching

Volume 4, Number 2, pp: 322-332, December 2020

e-ISSN: 2580-9962 | p-ISSN: 2580-8672

DOI: $10.30743 / I I . v 4 i 2.3152$

Table 9: Requirements for Speaking in English

\begin{tabular}{lcc}
\hline \multicolumn{1}{c}{ Category } & Sum & Percentage \\
\hline Can make questions and provide answers in the classroom & 3 & 3.75 \\
\hline Can participate in class discussions & 8 & 10 \\
\hline Presentation & 4 & 5 \\
\hline Can speak in seminars or international conferences & 17 & 21.25 \\
\hline Can talk with friends/people who come from abroad & 20 & 25 \\
\hline Can communicate with other people about the field of science & 23 & 28.75 \\
\hline Others & 5 & 6.25 \\
\hline
\end{tabular}

Table 10: Aspects That Need To Be Learned In English Courses

\begin{tabular}{|c|c|c|c|c|c|c|c|c|}
\hline \multirow{2}{*}{ Category } & \multicolumn{2}{|c|}{$\begin{array}{c}\text { Very } \\
\text { important }\end{array}$} & \multicolumn{2}{|c|}{ Urgent } & \multicolumn{2}{|c|}{$\begin{array}{l}\text { Quite } \\
\text { important }\end{array}$} & \multicolumn{2}{|c|}{$\begin{array}{c}\text { Not } \\
\text { important }\end{array}$} \\
\hline & Sum & $\%$ & Sum & $\%$ & $\begin{array}{l}\mathrm{Su} \\
\mathrm{m}\end{array}$ & $\%$ & Sum & $\%$ \\
\hline Fast and effective reading & 44 & 55 & 33 & 41.25 & 2 & 2.5 & 1 & 1.25 \\
\hline Pronunciation & 59 & 73.75 & 18 & 22.5 & 2 & 2.5 & 1 & 1.25 \\
\hline Punctuation & 41 & 51.25 & 33 & 41.25 & 6 & 7.5 & 0 & 0 \\
\hline $\begin{array}{l}\text { Special vocabulary according to the } \\
\text { field of science / special vocabulary }\end{array}$ & 40 & 50 & 35 & 43.75 & 5 & 6.25 & 0 & 0 \\
\hline General vocabulary & 42 & 52.5 & 35 & 43.75 & 3 & 3.75 & 0 & 0 \\
\hline $\begin{array}{l}\text { Write grammatically correct } \\
\text { sentences }\end{array}$ & 49 & 61.25 & 26 & 32.5 & 5 & 6.25 & 0 & 0 \\
\hline Make organized paragraphs & 32 & 40 & 41 & 51.25 & 7 & 8.75 & 0 & 0 \\
\hline Take notes from lectures & 34 & 42.5 & 38 & 47.5 & 8 & 10 & 0 & 0 \\
\hline $\begin{array}{l}\text { Summarize the contents of the } \\
\text { journal and so on }\end{array}$ & 25 & 31.25 & 40 & 50 & 14 & 17.5 & 1 & 1.25 \\
\hline Translate / translation & 48 & 60 & 31 & 38.75 & 1 & 1.25 & 0 & 0 \\
\hline Learn grammar & 49 & 61.25 & 25 & 31.25 & 6 & 7.5 & 0 & 0 \\
\hline $\begin{array}{l}\text { Listening to and understanding the } \\
\text { material related to the field of } \\
\text { science }\end{array}$ & 46 & 57.5 & 29 & 36.25 & 5 & 6.25 & 0 & 0 \\
\hline Spelling & 36 & 45 & 36 & 45 & 8 & 10 & 0 & 0 \\
\hline $\begin{array}{l}\text { Speak fluently about the field of } \\
\text { science }\end{array}$ & 51 & 63.75 & 24 & 30 & 5 & 6.25 & 0 & 0 \\
\hline $\begin{array}{l}\text { How to do a presentation properly } \\
\text { and correctly }\end{array}$ & 44 & 55 & 34 & 42.5 & 2 & 2.5 & 0 & 0 \\
\hline Speak incorrect grammar & 46 & 57.5 & 25 & 31.25 & 9 & 11.25 & 0 & 0 \\
\hline TOEFL strategies and exercises & 57 & 71.25 & 23 & 28.75 & 0 & 0 & 0 & 0 \\
\hline
\end{tabular}

The questions in table 5.9 are to find out what students need to learn in English courses. Of all the things mentioned in this question, students mentioned that it is very important to learn, especially those related to pronunciation (73.75\%), TOEFL strategies and exercises (71.25\%), speak fluently about the field of science $(63.75 \%)$, followed by writing sentences with correct grammar and learning grammar with the same percentage (61.75\%). While the things that are considered important are making organized paragraphs (51.25\%), summarizing journal contents and so on (50\%), and making notes from lectures (47.5\%) are the 3 highest percentages for important categories. For the unimportant category, reading fast and 
effective (very important/important / quite important / not important), pronunciation, and summarizing the contents of the journal, and so on were chosen by each 1 (one) student with a percentage of $1.25 \%$ for each question.

\section{Conclusion}

Based on the results of the data analysis carried out, the needs of non-English study program students in the UMSU environment show different and varied needs, according to their respective fields of knowledge. The average ability of students is at the intermediate / lower level, and speaking and listening skills are considered skills that are needed to be learned. Their learning objectives are divided into two criteria, short-term goals and long-term goals. Short-term needs are related to current needs such as academic/educational needs, while long-term goals are related to their world of work after completing education. The concept of ESP English learning required depends on the varying needs of each existing nonEnglish study program. Thus, the ESP concept that is designed must be tailored to these needs. In other words, which skills or aspects will be focused on in learning ESP English depends on the characteristics of each study program and the learner. These findings can be as the preliminary data for further research of ESP program.

\section{ACKNOWLEDGEMENTS}

The researchers would humbly express gratitude and appreciation to the University of Muhammadiyah Sumatera Utara for launching an internal research program under the coordination of Research and Community Service Institute of UMSU which provided fundi for this research with contract Number: 47 /II.3-AU/UMSU-LP2M/F/2020, by which this article can be published. To the respondents who had spent time to fill the questionnaires, and to all colleagues who had given their support during this research, the researchers would also like to convey great thanks.

\section{References}

Adnan, S. (2012). Needs analysis: a process to improve the learning of ESP at the college of administration-the department of Administration and Economy- university of Basra.The Arab Gulf, 40(1-2), 1-20. https://www.iasj.net/iasj/article/62389.

Afriazi, R. (2016). Pembelajaran Bahasa Inggris di Perguruan Tinggi Menghadapi Tantangan Abad XXI. Jurnal IImu Pendidikan, 7(1). http://journal.um.ac.id/index.php/jip/ article/view/592.

Ekayati, Rini. 2016. Optimalisasi Edmodo Dalam Meningkatkan Kemandirian Belajar dan Kesadaran Berbahasa Mahasiswa Semester VII Pada Mata Kulian LC Di Prodi Pendidikan Bahasa Inggris FKIP UMSU. Laporan Penelitian Teaching Grant, LPPM UMSU. Medan: UMSU.

Febriyanti, E. R. (2018). Identifikasi Analisis Kebutuhan Pembelajar Bahasa Inggris (Non Program Studi Bahasa Inggris) pada Mata Kuliah Bahasa Inggris ESP di Lingkungan FKIP Universitas Lambung Mangkurat Banjarmasin. Banjarmasin: Vidya Karya, 32(2), $123-$ 138.

Hamidah, F. N., \& Yanuarmawan, D. (2019). Penerapan English For Specific Purposes Untuk Meningkatkan Pengajaran Bahasa Inggris Pada Guru Sekolah Menengah Kejuruan. Jurnal ABDINUS: Jurnal Pengabdian Nusantara, 2(2), 236-247. https://ojs.unpkediri.ac.id/index.php/PPM/article/view/12767. 
Hossain, Md J. (2013). ESP Needs Analysis for Engineering Students: a Learner Centered Approach. Journal of Presidency University. 2(2), 16-26. http://presidency.edu.bd/ uploads/Article003.pdf.

Hutchinson, T. \& Waters, A. (1987). English for Specific Purposes: A Learning-Centered Approach. Cambridge: University Press.

Kusumaningputri, Reni. (2010). English for Specific Purpose di UniversitasJember: Tantangan danSolusi. PengembanganPendidikan. 7(2), 182-189. https://media.neliti.com/ media/publications/210263-english-for-specific-purposes-diuniversi.pdf.

Megawati, F. (2016). Kesulitan mahasiswa dalam mencapai pembelajaran bahasa Inggris secara efektif. PEDAGOGIA: Jurnal pendidikan, 5(2), 147-156. http://ojs.umsida.ac.id/index.php/pedagogia/article/view/246/227.

Robinson, P.C. (1991). ESP Today: A Practitioner's Guide. Englewood Cliffs, NJ: Prentice H. Sugiyono. (2010). Metode Penelitian Kuantitatif Kualitatif dan R\&D. Bandung: Alfabeta 